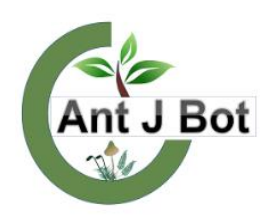

Received : 26.12.2017 Accepted : 20.01.2018

\section{Use of lichens as natural insecticide}

\author{
Bugrahan EMSEN ${ }^{1 *}$, Ali ASLAN ${ }^{2}$ \\ ${ }^{1}$ Karamanoğlu Mehmetbey University, Kamil Özdă̆ Science Faculty, Department of Biology, Karaman, Turkey \\ ${ }^{2}$ Yuzuncu Yil University, Faculty of Pharmacy, Department of Pharmacology, Van, Turkey \\ *bugrahanemsen@gmail.com
}

\section{Likenlerin doğal insektisit olarak kullanımı}

\begin{abstract}
Agriculture has become one of the greatest sources of employment for mankind from the past to the present. The products obtained in this area provide a significant contribution to the national economies. However, the number of organisms causing the decline in crop yield is quite high. The preferred applications for combating harmful organisms are the use of chemical insecticides. However, the high level of side effects of these insecticides led researchers to alternative study areas. Insecticide production through natural products that is under the title of biological struggle, is within popular areas. Lichens are also materials for natural insecticide sources due to their unique constituents in the constructions. For many years, the toxic effects of lichens utilized in many fields on different insect species have been tested through their extracts and pure components. At this point, it is noteworthy that while high yield is obtained from lichens, the studies are predominantly carried out on the extracts. In the light of all these studies, it will be contributed to biological insecticide production stage by increasing of the studies performed on determination of the active components in lichens showing insecticidal activity on different species and on mechanisms of action in insects.
\end{abstract}

Key words: Extract, Insecticide, Lichen, Metabolite

Özet: Tarım, geçmişten günümüze kadar insanoğlu için en büyük istihdam kaynaklarından biri olmuştur. Bu alanda elde edilen ürünler ülke ekonomilerine önemli ölçüde katkı sağlamaktadır. Bununla birlikte, ürün veriminde düşüşlere sebep olan organizma sayısı bir hayli fazladır. Zararlı organizmalar ile mücadele konusunda tercih edilen uygulamaların başında kimyasal insektisit kullanımı gelmektedir. Fakat bu insektisitlerin yan etkilerinin yüksek düzeyde olması araştırmacıları alternatif çalışma konularına yönlendirmiştir. Biyolojik mücadele başlı̆̆ı altında ele alınan, doğal ürünler aracılığı ile insektisit üretimi popüler alanlar içerisinde yer almaktadır. Likenler de yapılarında bulunan kendilerine özgü bileşenleri sayesinde doğal insektisit kaynaklarına malzeme olmaktadır. Yıllardır birçok alanda yararlanılan likenlerin gerek ekstraktları gerekse saf bileşenleri aracılığı ile farklı böcek türleri üzerinde toksik etkileri test edilmektedir. Bu noktada, likenlerden yüksek oranda verim elde edilmekle beraber çalışmaların ağırlıklı olarak ekstraktlar üzerinde gerçekleştirildiği dikkat çekmektedir. Tüm bu çalışmalar 1şığında, farklı türler üzerinde insektisit aktivite gösteren likenlerdeki aktif bileşenlerin ve böceklerdeki etki mekanizmalarının tespiti üzerine gerçekleştirilecek çalışmaların artırılması ile biyolojik insektisit üretim basamağına katkı sağlanacaktır.

Anahtar Kelimeler: Ekstrakt, İnsektisit, Liken, Metabolit

\section{Introduction}

The goal in all past studies is to develop insecticides that can only be effective on the harmful target organism, taking care not to disturb the natural balance without affecting the environment and human health. In this direction, the researchers have been working in the last years and serious studies have started to be done on herbal insecticides (Pant et al., 2016). Natural herbicide insecticides constitute $1 \%$ of the world insecticide market. As more work is done on organic agriculture than in the past, annual sales increase by about $10-15 \%$ per year (Isman, 1997).

Many researchers have proved that plants are potential sources of insecticides. It was reported that many plant species affect various forms of insects which are harmful to agriculture. Despite the fact that so many of the plants are known to have the insecticidal effect, few have been used in practice. Isman (1997) cites the reasons for this, as natural resources are limited, standardization and licensing difficulties. Natural insecticides have some advantages and disadvantages compared to synthetic insecticides. Natural insecticides break down very quickly in sunlight, humidity and windy conditions, so they can be used just before harvesting. However, many of these insecticides stop feeding their insects very quickly, although they do not kill them immediately. Therefore, it sometimes takes a few days for the death of the insects, but it has a rapid effect in terms of prevention of damage (Oberemok et al., 2015).

If we exclude some highly toxic plant-based insecticides, it can be said that most of the plant-derived natural insecticides are not toxic to mammals and the environment. Rapid disintegration and stomach poisoning make natural insecticides more selective against plantfeeding harmful insects (Walia et al., 2017). Natural insecticides are not usually phytotoxic. They also have no negative effects on their germination, growth and product quality. However, nicotine may have a negative effect on some ornamental plants. When they are used in their natural form, the risks of creating durability are practically absent. They can be obtained cheaper and easier than synthetic insecticides in those areas, as they grow mostly in areas with less developed and lower labor costs (Sierro et al., 2013).

The compounds that plants cause to act on the insects are secondary metabolites that secrete at the time of stress (Rattan, 2010). Herbal substances used against insects are compounds which are obtained by various methods from plants and show insecticidal properties. These can be in various forms, such as unprocessed plant materials, plant extracts, and pure compounds isolated from plants. While some of the natural insecticides are used directly as lethal, 
others have repellent and nourishment-inhibiting properties (Murugesan et al., 2016).

The action mechanisms of insecticides are generally on the nervous and digestive system of the organism. Insecticides of plant origin are said to have entered the body of insects through contact and poisoned the nervousmuscle system via secondary metabolites (Denecke et al., 2015). In addition, it has also been found that herbal insecticides affect physiology of the insect by acting in different forms on various receptor sites (Buckingham et al., 2017)

It is known that plant-based insecticides have effect a number of harmful species. Yildirim et al. (2005) have investigated the effect of three essential oil extracts on Tribolium confusum (du Val) which damages products such as flour and flour produced pasta, biscuits, bran, soup material, starch and some oil seeds and Sitophilus granarius (L.) damaging in stored seed known as wheat weevil. As a result of the experiment, mortality rate of $67 \%$ for $T$. confusum and $43 \%$ for $S$. granarius appeared. In another study, fumigant toxicity effect of essential oils from nine plant species on adults of $S$. granarius was investigated (Kordali et al., 2012).

Y1ldırım et al. (2009) have evaluated effectiveness of plants grown from pesticide seeds against cabbage aphid (Brevicoryne brassicae L.), cabbage leaf fleas (Phyllotreta atra F., Phyllotreta nigripes F.), cabbage moth (Plutella xylostella L.) and large cabbage butterfly (Pieris brassicae L.). As a result, it was detected that the damage of leaf fleas in cabbage plants was considerably reduced and after six weeks, the loss was reduced by $90 \%$. Many studies that demonstrate that some medical plants have the same effect as some chemical insecticides are also included in the literature (Tewary et al., 2005; Kordali et al., 2013; Yildirim et al., 2013). In recent years, insecticidal activity studies carried out through compounds derived from in vitro propagated plants have also gained popularity (Emsen et al., 2016; Dogan et al., 2017).

Since plant origin ones among the insecticides used in the struggle with harmful organisms act differently on the target organism without harming the environment, their usage areas have expanded.

\section{General Characteristics of Lichens}

Among the many species of organisms used for the purpose of obtaining insecticides, lichens are the most remarkable species. Lichens are very interesting livings with their forms of formation, their living habits, their diversity of uses, and their components that they have in their structure. According to Nash (2008), lichens are symbiotic organisms formed with a fungus partner called a mycobiont and by the photosynthetic partner which can be one or more algae or cyanobacteria and is known as a photobion. Lichens show a completely separate structure from the algae and fungi that form themselves in terms of shape and life. The photosynthetic organism (photobiont) involved in the structure of a colorless fungal hyphae is usually green algae or a cyanobacterium; but they are also known to be composed of some yellow-green algae and brown algae (Bačkor and Fahselt, 2008). Some of the genus belonging to Cyanophyta and Chlorophyta and some algae from Xanthophyta and Phaeophyta are observed. Mushrooms are usually Ascomycetes and rarely belonging to Basidiomycetes (Grube and Spribille, 2012; Millot et al., 2016).

In the periods when the lichens first began to be examined, although the fungus in the lichen symbiosis was thought to have benefited from algae such as parasites due to lack of chlorophyll, but later this explanation lost its significance. It has been understood that the fungus has been supplied with water and water-soluble minerals from the environment in common life with the help of hyphae (Brodo et al., 2001; Nash, 2008). Fungi that can not produce their own carbohydrates meet the needs for glucose from photosynthesizing algae and cyanobacteria thanks to the chlorophyll pigment contained. Starch is also used as a storage material in lichens (Rikkinen, 2015; Suzuki et al., 2016).

For years, many scientists have gone to the way of classifying lichens by adding their own interpretation. One of these classifications is based on the environment on which lichens live. According to this, lichens are divided as living on limestone rocks, siliceous soils, tree trunks and branch bark, leaves, overturned tree logs, and in water. Another classification has been made according to the type of fungus found in the lichen species. In this case, lichens are divided into three classes as Phycolichens, Ascolichens and Basidiolichens (Brodo et al., 2001). Nowadays, the most important classification accepted by many scientists is to group lichens according to thallus structures. The thallus structures found in lichens show the character of this lichen. Because, in many cases, a great deal of a lichen comes from the thallus, unlike the reproductive and reproduction processes. According to thallus structure, lichens are divided into three groups, namely crustose, foliose and fruticose (Sipman, 2002; Armstrong and Bradwell, 2010).

Among the lichens, the species that are short-lived are rare. Although there are environmental issues that reduce the lifespan of lichens like other life forms, they can survive for more than 1000 years under favorable conditions such as fresh air, adequate humidity and light (Armstrong, 2004). Lichen species are very susceptible to polluted air, so the lichen flora is very poor in industrial areas and near large cities. On the other hand, the lichens cover the rocks, tree trunks and branches in various colors and shapes in clean air areas. For this reason, they are indicator organisms for the cleanliness of a zone's air (Szczepaniak and Biziuk, 2003; Rikkinen, 2015).

Lichens are distributed almost everywhere in the world. They are able to develop even in the desert where there is enough humidity, Arctic and Antarctic regions, the freezing temperatures of high mountains, on the stones that other plants can not live on, inefficient soil, dry tree bark and tiles (Kranner et al., 2008). The feature that allows lichens to survive on extreme conditions is hidden in the acids in their structure. Lichen acids, the secondary metabolites of lichens, give the lichens the ability to become a preliminary organism in the primary succession in the nature. The sandy, rocky, clayey, marsh and gravel environments are primarily occupied by lichens. These are called leading populations. At this point, lichens increase the soil quality of the environment (Xu et al., 2005; Zambare and Christopher, 2012; Nguyen et al., 2013). 


\section{Different Usage Areas of Lichens}

Due to the lichen acids produced by the fungi in the symbiotic life of lichens, since the past centuries it was benefitted from the lichens in many areas. For example; in the past, during scarcity in Scandinavia, Cetraria islandica (L.) Ach. was milled and added to wheat flour or potatoes to increase insufficient supplies. In the 1880s in Sweden, Cladina rangiferina (L.) Nyl. was used as a sugar source (Brodo et al., 2001). C. islandica and Lobaria pulmonaria (L.) Hoffm. have been used for skin tanning because of their shrunken properties. L. pulmonaria has also been used in the fermentation of beer. It has been found that the beer made with this lichen is exactly the same as the one made with hops (Tutel, 1986).

Most of the Rocella species from lichens were used in the dyeing of wool and clothes until the mid-19th century. Two different color substances were identified among Rocella species. There is erythrin acid in Roccella fuciformis (L.) DC., Rocella fucoides (Dicks.) Vain., Rocella peruensis Krempelh., Lecanora montagnei (Fr.) Schaer. and lecanorin acid was determined in Roccella tinctoria DC., Roccella sinensis Nyl. and Cladonia portentosa ((Dufour) Coem.) (Aslan, 1995; Culberson and Culberson, 2001). Evernia prunastri (L.) Ach., Pseudevernia furfuracea (L.) Zopf., L. Pulmonaria, Anaptychia ciliaris (L.) Körb. and some Usnea sp., Physcia sp. were used in the field of cosmetics. These lichens are used in perfume as a mixture, not alone. The lichens that increase the persistence of smell give a pleasant fragrance to the combination of perfume (Tutel, 1986).

The lichens were also used in the medical field. The lichen species in this area are generally used with meaning according to their morphological appearance. $L$. pulmonaria was used as a softening cream in the treatment of pulmonary disease for pulmonary resemblance. Usnea Florida (L.) Weber ex F.H. Wigg. and many other Usnea species, which are filamentous and resembling hair, were used to prevent hair loss and to make hair look louder and more vibrant. Xanthoria parietina (L.) Beltr. which has a yellow-orange color and Peltigera apthosa (L.) Willd. which is similar to the small warts in the thallus were used in the treatment of jaundice and canker diseases, respectively (Brodo et al., 2001).

Lichens are used in the form of laxatives, expectorants, tonic, internal or external pastes, decoction (boiling) or infusion. In various parts of the world, researches are being conducted for new pharmaceutical uses of lichens (Shukla et al., 2010). It has been found that some lichens have antitumor activity through components such as polysaccharide, glucan and glycoprotein. Antimicrobial activities against different bacterial species were identified in lichens where many antibiotic substances were detected (Shrestha and St. Clair, 2013; Shrestha et al., 2015).

\section{Insecticidal Efficacies of Lichens}

It is also necessary to add the insecticide activities to the above-mentioned and many other unused usage areas of lichens. It was reported that Letharia vulpina (L.) Hue ve Vulpicida pinastri (Scop.) J.-E. Mattsson species are toxic and these lichens have been used in some European and Scandinavian countries to kill wolves and foxes that have damaged to animals in winter. When these species are eaten by animals, they cause death by stopping breathing, particularly by influencing the respiratory system. Brodo et al. (2001) reported that a lichenologist who collected $L$. vulpina from these toxic species in large quantities severely undergone respiratory tract irritation since he was constantly in contact with this species and this person had a nosebleed. This event suggests that these lichen species may also be poisonous to humans. Some researchers, considering these properties of lichens, have gone to investigate the insecticidal effect of lichens.

Cetin et al. (2008) investigated the insecticidal effects of ()-usnic acid and (+)-usnic acid secondary metabolites obtained from Cladonia foliaceae (Huds.) Wield. and Ramalina farinacea (L.) Ach. against Culex pipiens L. (mosquito) larvae in laboratory conditions and get $100 \%$ results in some biological periods of these organisms. 1440 samples from 50 lichen species with different chemical properties were analyzed to determine whether these characteristics of lichens-fed insects originated from lichen species, particularly lichen chemistry by Nimis and Skert (2006). Multivariate analyzes revealed a special negative correlation between the presence of grass-fed animals and some lichen substances.

Silva et al. (2009) examined potential insecticide effects of lectin isolated from Cladonia verticillaris (Raddi) Fries on Nasutitermes corniger Motschulsky termite. As a result of their work, it was stated that $C$. verticillaris preparations might be able to control termites (or other insects) that are economically related to agriculture and the wood industry. In another study, the effects of methanol, chloroform and water extracts of L. pulmonaria on the life span of Drosophila melanogaster Meigen (vinegar fly) were investigated (Uysal et al., 2009). They found that methanol extract was more effective than chloroform and water extracts and water extract was relatively weaker than methanol and chloroform extracts. Emmerich et al. (1993) investigated the antifeedant and lethal effects of four of the lichen metabolites, (-)- and (+)-usnic acid, vulpinic acid, and stictic acid on Spodoptera littoralis Boisduval larvae. They noted that both types of usnic acid as well as vulpinic acid showed a lethal effect at high levels and delayed growth. It was also detected that stictic acid did not show any effect.

In various treatments, it was reported that larval killer effect of usnic acid and vulpinic acid was tested on Bemisia tabaci Gennadius (white fly) and vulpinic acid was more effective than (-)- usnic acid. In addition, it was determined that hexane, ethyl acetate, methanol and water extracts of Roccella montagnei Bél. had a lethal effect on Helicoverpa armigera (Hubner) Among (green worm) (Balaji et al., 2007). Another lichen-insecticide related study was performed on Usnea sp., Heterodermia diademata (Taylor) D.D. Awasthi, Roccella montagnei Bél. and Leproloma sipmanianum Kümmerl \& Leuckert. from lichen species. In the related work, high insecticidal effect of ambewelamide A compound isolated from aforementioned lichens was determined on the second period larvae of Aedes aegypti (L.). In another study performed with the same larvae, it was pronounced that cabraleadiol monoacetate and 3,6-dimethyl-2-hydroxy-4methoxybenzoic acid from lichen acids had insecticidal activity (Tufan Çetin and Sümbül, 2008). 
In recent years, efforts to create biological insecticides against storage pests through different lichen extracts and components have gained popularity. Emsen et al. (2012b) observed toxicity of Cladonia foliacea (Huds.) Willd. and Flavoparmelia caperata (L.) Hale on grain weevil, Sitophilus granarius (L.) and reported 91 and 83\% mortality rates for both species, respectively. Similarly, experiments carried out with L. vulpina, Lecanora muralis (Schreb.) Rabenh. and Peltigera rufescens (Weiss) Humb revealed other lichen species that was effective on $S$. granarius (Emsen et al., 2015). In that study where concentration-dependent insecticidal activity was observed, median lethal concentration $\left(\mathrm{LC}_{50}\right)$ values of $L$. vulpina, L. muralis and P. rufescens were $0.51,0.67$ and 0.33 , respectively. Insecticidal activities caused by extracts of L. vulpina, L. muralis and P. rufescens were 100,86 and $100 \%$, respectively.

There are also studies in which insecticidal effects of active ingredients isolated from lichens against grain weevil are tested. Yildirim et al. (2012a) obtained diffractaic and usnic acid from Usnea longissima Ach. and measured insecticidal effect of these secondary metabolites. Although they found that both compounds had high activity, it was revealed that usnic acid was more effective than diffractaic acid. Another insect that causes loss in warehouse products is Sitophilus zeamais Motschulsky. Lichens were also used to combat with this pest through natural insecticide. Diffractaic acid and usnic acid from pure lichen compounds and L. vulpina, $P$. rufescens extracts were tested against $S$. zeamais and positive results achieved (Yildirim et al., 2012b). In previously mentioned study, the highest mortalities belonged to $L$. vulpina extract and diffractaic acid with 96.97\%. L. vulpina, L. muralis and P. rufescens have taken place among lichens used for solution to potato beetle (Leptinotarsa decemlineata Say) that damages an important agricultural product, potato. The insecticidal activities of L. vulpina and $P$. rufescens after 120 hours was remarkable (Emsen et al., 2013). In the same way, when measured the toxicity efficacies of diffractaic and usnic acids isolated from U.longissima against 4th instar larvae and adults of $L$. decemlineata, it was determined that the activity levels of mentioned compounds were significant after 96 hours (Emsen et al., 2012a).

The lichens that are used in different areas due to their unique compounds also have a place in the field of biological insecticide. However, total extracts are noteworthy in the studies carried out so far for natural insecticide production field. In the future, increasing of the studies performed on detection of the active components that play insecticidal role in the lichens and on insect death mechanisms will contribute much more to the field of biological insecticide production.

\section{Conflicts of interest}

There is no conflict of interest in any form between the authors.

\section{References}

Armstrong RA (2004). Lichens, Lichenometry and Global Warming. In: Microbiologist. pp 32-35.

Armstrong R, Bradwell T (2010). Growth of Crustose Lichens: A Review. Geogr Ann Ser A, Phys Geogr 92: 3-17.

Aslan A (1995). Erzurum-Kars-Artvin Arasında Yer Alan Bölge Likenleri Üzerine Taksonomik İncelemeler. Doctorate Thesis, Uludağ University Institute of Science and Technology, Bursa, Turkey.

Bačkor M, Fahselt D (2008). Lichen Photobionts and Metal Toxicity. Symbiosis 46: 1-10.

Balaji P, Malarvannan S, Hariharan GN (2007). Efficacy of Roccella montagnei Extracts on Helicoverpa armigera (Lepidoptera: Noctuidae). J Entomol 4: 248-252.

Brodo IM, Sharnoff SD, Sharnoff S (2001). About the Lichens. In: Lichens of North America. Yale University Press, New Haven \& London, pp 3-113.

Buckingham SD, Ihara M, Sattelle DB, Matsuda K (2017). Mechanisms of Action, Resistance and Toxicity of Insecticides Targeting GABA Receptors. Curr Med Chem 24: 2935-2945.

Cetin H, Tufan-Cetin O, Turk AO, Tay T, Candan M, Yanikoglu A, Sumbul H (2008). Insecticidal Activity of Major Lichen Compounds, (-)- and (+)-Usnic Acid, against the Larvae of House Mosquito, Culex pipiens L. Parasitol Res 102: 12771279.

Culberson CF, Culberson WL (2001). Future Directions in Lichen Chemistry. Bryologist 104: $230-234$.

Denecke S, Nowell CJ, Fournier-Level A, Perry T, Batterham P (2015). The Wiggle Index: An Open Source Bioassay to Assess Sub-Lethal Insecticide Response in Drosophila melanogaster. Plos One 10: e0145051.

Dogan M, Emsen B, Aasim M, Yildirim E (2017). Ceratophyllum demersum L. Extract as a Botanical Insecticide for Controlling the Maize Weevil, Sitophilus zeamais Motschulsky (Coleoptera: Curculionidae). Egypt J Biol Pest Control 27: 11-15.

Emmerich R, Giez I, Lange OL, Proksch P (1993). Toxicity and Antifeedant Activity of Lichen Compounds against the Polyphagous Herbivorous Insect Spodoptera littoralis. Phytochemistry 33: 1389-1394.

Emsen B, Bulak Y, Yildirim E, Aslan A, Ercisli S (2012a). Activities of Two Major Lichen Compounds, Diffractaic Acid and Usnic Acid against Leptinotarsa decemlineata Say, 1824 (Coleoptera: Chrysomelidae). Egypt J Biol Pest Control 22: 510.

Emsen B, Yildirim E, Aslan A, Anar M, Ercisli S (2012b). Insecticidal Effect of the Extracts of Cladonia foliacea (Huds.) Willd. and Flavoparmelia caperata (L.) Hale Against Adults of the Grain Weevil, Sitophilus granarius (L.) (Coleoptera: Curculionidae). Egypt J Biol Pest Control 22: 145-149.

Emsen B, Aslan A, Yildirim E, Ercisli S (2013). Toxicity Effects of Some Lichen Species Extracts against the Colorado Potato Beetle, Leptinotarsa decemlineata Say (Coleoptera: Chrysomelidae). Egypt J Biol Pest Control 23: 193-199. 
Emsen B, Yildirim E, Aslan A (2015). Insecticidal Activities of Extracts of Three Lichen Species on Sitophilus granarius (L.) (Coleoptera: Curculionidae). Plant Prot Sci 51: 156-161.

Emsen B, Dogan M, Aasim M, Yildirim E (2016). Insecticidal Activity of In Vitro Propagated Aquatic Plant Ceratophyllum demersum L. against Granary Weevil Sitophilus granarius L. (Coleoptera: Curculionidae). Egypt J Biol Pest Control 26: 619-624.

Grube M, Spribille T (2012). Exploring Symbiont Management in Lichens. Mol Ecol 21: 3098-3099.

Isman MB (1997). Neem and Other Botanical Insecticides: Barriers to Commercialization. Phytoparasitica 25: 339-344.

Kordali S, Yildirim E, Yazici G, Emsen B, Kabaagac G, Ercisli S (2012). Fumigant Toxicity of Essential Oils of Nine Plant Species from Asteraceae and Clusiaceae against Sitophilus granarius (L.) (Coleoptera: Curculionidae). Egypt J Biol Pest Control 22: 11-14.

Kordali S, Emsen B, Yildirim E (2013). Fumigant Toxicity of Essential Oils from Fifteen Plant Species against Sitophilus zeamais Motschulsky (Coleoptera: Curculionidae). Egypt J Biol Pest Control 23: 241-246.

Kranner I, Beckett R, Hochman A, Nash TH (2008). Desiccation-Tolerance in Lichens: A Review. Bryologist 111: 576-593.

Millot M, Dieu A, Tomasi S (2016). Dibenzofurans and Derivatives from Lichens and Ascomycetes. Nat Prod Rep 33: 801-811.

Murugesan S, Senthilkumar N, Babu DS, Rajasugunasekar D (2016). Chemical Composition, Antifeedant and Insecticidal Activities of Tree Borne Oil Seeds. Pestology 40: 29-41.

Nash TH (2008). Lichen Biology. Cambridge University Press, New York, p 486.

Nguyen K-H, Chollet-Krugler M, Gouault N, Tomasi S (2013). UV-Protectant Metabolites from Lichens and Their Symbiotic Partners. Nat Prod Rep 30: 1490-1508.

Nimis PL, Skert N (2006). Lichen Chemistry and Selective Grazing by the Coleopteran Lasioderma serricorne. Environ Exp Bot 55: $175-182$.

Oberemok VV, Laikova KV, Gninenko YI, Zaitsev AS, Nyadar PM, Adeyemi TA (2015). A Short History of Insecticides. J Plant Prot Res 55: 221-226.

Pant M, Dubey S, Patanjali PK (2016). Recent Advancements in Bio-Botanical Pesticide Formulation Technology Development. In: Herbal Insecticides, Repellents and Biomedicines: Effectiveness and Commercialization. pp 117-126.

Rattan RS (2010). Mechanism of Action of Insecticidal Secondary Metabolites of Plant Origin. Crop Prot 29: 913-920.

Rikkinen J (2015). Cyanolichens. Biodivers Conserv 24: 973-993.

Shrestha G, St. Clair LL (2013). Lichens: A Promising Source of Antibiotic and Anticancer Drugs. Phytochem Rev 12: $229-244$.

Shrestha G, St. Clair LL, O’Neill KL (2015). The Immunostimulating Role of Lichen Polysaccharides: A Review. Phyther Res 29: 317-322.

Shukla V, Joshi GP, Rawat MSM (2010). Lichens as a Potential Natural Source of Bioactive Compounds: A Review. Phytochem Rev 9: 303-314.

Sierro N, Battey JN, Ouadi S, Bovet L, Goepfert S, Bakaher N, Peitsch MC, Ivanov NV (2013). Reference Genomes and Transcriptomes of Nicotiana sylvestris and Nicotiana tomentosiformis. Genome Biol 14: R60.

Silva MDC, Sá RA, Napoleão TH, Gomes FS, Santos NDL, Albuquerque AC, Xavier HS, Paiva PMG, Correia MTS, Coelho LCBB (2009). Purified Cladonia verticillaris Lichen Lectin: Insecticidal Activity on Nasutitermes corniger (Isoptera: Termitidae). Int Biodeterior Biodegrad 63: 334-340.

Sipman HJM (2002). The Significance of the Northern Andes for Lichens. Bot Rev 68: 88-99.

Suzuki MT, Parrot D, Berg G, Grube M, Tomasi S (2016). Lichens as Natural Sources of Biotechnologically Relevant Bacteria. Appl Microbiol Biotechnol 100: 583-595.

Szczepaniak K, Biziuk M (2003). Aspects of the Biomonitoring Studies Using Mosses and Lichens as Indicators of Metal Pollution. Environ Res 93: 221-230.

Tewary DK, Bhardwaj A, Shanker A (2005). Pesticidal Activities in Five Medicinal Plants Collected from Mid Hills of Western Himalayas. Ind Crops Prod 22: 241-247.

Tufan Çetin Ö, Sümbül H (2008). Liken Ekstraktları ve Sekonder Bileşiklerinin Böcek Kontrolünde Kullanımları. Türk Liken Topluluğu Bülteni 5: 8-10.

Tutel B (1986). Liken Biyolojisi ve Faydalar1. Marmara Üniversitesi Eczac Fakültesi Derg 2: 185-194.

Uysal H, Altun D, Aslan A (2009). Drosophila melanogaster'de Lobaria pulmonaria (L.) Hoffm. Likeninin Ömür Uzunluğu Üzerine Etkisi. TÜBAV Bilim Derg 2: 271-276.

Walia S, Saha S, Tripathi V, Sharma KK (2017). Phytochemical Biopesticides: Some Recent Developments. Phytochem Rev 16: 989-1007.

Xu ZQ, Li WH, Bao WK, Xu Q (2005). A Review on Primary Succession of Vegetation. Acta Ecol Sin 25: 3383-3389.

Yildirim E, Kesdek M, Kordali S (2005). Effects of Essential Oils of Three Plant Species on Tribolium confusum Du Val and Sitophilus granarius (L.) (Coleoptera: Tenebrionidae and Curculionidae). Fresenius Environ Bull 14: 574-578.

Yıldırım E, Çalmaşur Ö, Kesdek M (2009). Imidacloprid, Thiamethoxam and Cyromazine Seed Treatments for the Control of Cabbage Insect Pests in Erzurum, in Turkey. Atatürk Univ J Agric Fac 40: 23-34. 
Yildirim E, Aslan A, Emsen B, Cakir A, Ercisli S (2012a). Insecticidal Effect of Usnea longissima (Parmeliaceae) Extract against Sitophilus granarius (Coleoptera: Curculionidae). Int J Agric Biol 14: 303-306.

Yildirim E, Emsen B, Aslan A, Bulak Y, Ercisli S (2012b). Insecticidal Activity of Lichens against the Maize Weevil, Sitophilus zeamais Motschulsky (Coleoptera: Curculionidae). Egypt J Biol Pest Control 22: 151-156.

Yildirim E, Emsen B, Kordali S (2013). Insecticidal Effects of Monoterpenes on Sitophilus zeamais Motschulsky (Coleoptera: Curculionidae). J Appl Bot Food Qual 86: 198-204.

Zambare VP, Christopher LP (2012). Biopharmaceutical Potential of Lichens. Pharm Biol 50: 778-798.

Cite this article: Emsen B, Aslan A (2018). Use of lichens as natural insecticide. Anatolian Journal of Botany 2(1): 22-27. 